\title{
The Last Revolt of Bashmūr (831 A.D.) in Coptic and Syriac Historiography
}

\author{
Myriam Wissa
}

In 831 A.D., parts of the Muslim and Coptic population in Egypt undertook a major uprising against Abbasid domination and against an oppressive caliphal tax regime in the provinces. The rebellion was aggressively put down by the Abbasid governor in most of Egypt with the exception of the region of Bashmūr. Here, in the northern Nile Delta, Copts were to continue to heavily resisting central rule for a long period. The conflict had revolved around temporal and spiritual powers and was the religious-political issue of the time.

Earlier studies devoted to the events have invariably dealt with the onerous Abbasid tax regime as a main reason for the rebellion, which in its aftermath resulted in sizeable conversions to Islam in all of Egypt. In the following, I will focus on another aspect, which is the role of arbitration by the Coptic and Syriac patriarchs, Yūsāb I and Dionysius, in the handling of the conflict. My object of study is the processes of conciliation and the post-conflict outcome (forced migration, deportations and displacements?) as depicted in the Coptic and Syriac narratives of two central historiographical works, the History of the Patriarchs of Alexandria on the one hand, and the History of Dionysius of Tell Mahre on the other. ${ }^{1}$

\section{Coptic and Syriac Historiography: A Note on the Sources}

Historical accounts written in Coptic or Syriac contribute important details on the situation of individuals, non-Muslims (dhimmīs) and Muslims alike, under caliphal rule. In contrast to a more dominant Arabic historiography, however Christian sources consist only of a scanty corpus since they were cultivated by monks, deacons and bishops, and were merely ecclesiastically and religiously

1 This article is part of a broader research, see M. Wissa, The Last Revolt of Bashmur, 831-832 A.D.: Event, Narrative, and Transformation in the Medieval Delta (in preparation). I owe a debt of gratitude to Sebastian Brock (Oxford) and Dorothea Weltecke (Frankfurt am Main) for their feedback on the Syriac sources. 
prompted. This literature is a combination of historical, religious, sociographic and ethnographic studies including such subjects as topography, religious institutions (churches and monasteries), economic, cultural and social life along with political groups from within and without. How do these works offer an insight into the historical events and their outcome? Indeed Coptic and Syriac chroniclers adopted a theocentric view of the devastating events such as famine and persecutions. This should not undermine the importance of historicism and context in Christian literature that can contribute to our understanding of the situation of non-Muslims (dhimmīs) under gth century Muslim rule. ${ }^{2}$

\subsection{The Coptic Tradition: History of the Patriarchs of Alexandria}

The History of the Patriarchs of Alexandria, which is not known in the "primitive" authorial recension edition but is available in a "vulgate" version, was transmitted in a considerable number of manuscripts scattered throughout libraries and archives in both Europe and Egypt. ${ }^{3}$ The History of the Patriarchs had originally been compiled and translated from Coptic sources into Arabic by the Alexandrian notable Mawhūb ibn Manșūr ibn Mufarrij (c. 1025-1100). ${ }^{4}$ Mawhūb had utilised five Coptic historical texts, with the exception of the first one all others are now lost: (1) the so-called History of the Church in Sahidic Coptic, covering the early period from 60 to $451 i^{5}(2)$ another chronicle written by an early 8th century writer with the name George the Archdeacon which must have covered the period from 412 to approximately 700; (3) a third chronicle written by a monk called John, from the middle of the 8th century; (4) a fourth chronicle that had been written by another monk called John, during the years $865^{-866 ;}$ (5) and finally a fifth chronicle written by Mikhail, bishop of Tinnīs, in $105^{1}$ or 1058. Alongside these five main Coptic source texts, Mawhūb

2 Debié, L'écriture de l'histoire, p. 147 supports this evidence: "Les sources chrétiennes donnent ainsi une image 'de terrain' des relations entre le pouvoir central et celui des provinces".

3 The first part of the primitive recension of the History of the Patriarchs was identified by C. Brockelmann and has been edited separately by Ch. Seybold in 1912. The second and third parts were identified by Den Heijer, "L'Histoire des Patriarches d'Alexandrie". On a new conceptualisation of the transmission and the dichotomy between a primitive edition and a "vulgate" version, see Pillette, "L'Histoire des Patriarches d'Alexandrie".

4 Den Heijer, Mawhub ibn Manșur; idem, "History of the Patriarchs of Alexandria". The Arabic text produced by Mawhūb using the earlier versions is arranged in a series of sixty five Coptic patriarchs' biographies.

5 The first part of this History of the Church relies on Eusebius of Caesarea's Greek Historia Ecclesiastica. The second part is an original composition produced entirely in a Coptic milieu and attributed to an unknown author called Menas who may have had been a monk at the monastery of Saint Shenoute in Sohag. 
had occasionally resorted to additional sources. ${ }^{6}$ The inside story of the Bashmūric rebellion is reported in the Coptic Chronicle of John II (767-880), ${ }^{7}$ the author of Lives $47^{-55}$ of the History of the Patriarchs. ${ }^{8}$ John makes it clear that the material coverage of the events in 9 th century Egypt stands to provide a literary-historical information on local Abbasid history. His, John's, writing strategy on the unrest that hit Egypt from below in the last years of the reign of Hārūn al-Rashīd (ruled 786-809) provides a good insight into the context of the early Abbasid caliphate.

\subsection{The Syriac Tradition: History of Dionysius of Tell Mahre}

Syriac historiographical tradition, on the other hand, had produced some vibrant chroniclers such as Jacob of Edessa (684-687/88), Dionysius of Tell Mahre (818-845), Michael I (1166-1199), and the maphrian Bar 'Ebroyo (12641286). Dionysius wrote a history of the period between 582 and 842 in two parts: a Church history, which most likely came first; and a World history, making sixteen books in all. His work almost entirely being lost (with the exemption of a single folio page ${ }^{9}$ ), it can only partly be reconstructed from material common to later chronicles. Extant fragments of his work can be found in the Chronicle of Michael the Syrian..$^{10}$ Even more significant is the anonymous Chronicle of 1234, which also contains some of the material known from Michael the Syrian. ${ }^{11}$ The Chronicle of 1234 retains the narrative structure of the original but remains the principal source for the History of Dionysius of Tell Mahre. ${ }^{12}$ Dionysius tells the story of the uprising in eloquent words, highlighting his social status, his good relationship with the Abbasid caliph, and the wickedness of local governors as well as his role as a mediator. ${ }^{13}$

6 An outline of Mawhūb's additional sources is given in Heijer, Mawhub ibn Manșur, pp. 3-7; $117-156$.

7 While evidence for author's name is not decisive, it has become standard in den Heijer, Mawhub ibn Manșur to refer to this author as "John II". Swanson, Coptic Papacy, p. 27, on the other hand, chose to call him "John the Writer".

8 Evetts, History of the Patriarchs.

9 Vatican, BAV, vat. Syr. 144.

10 The fragments are published in Brooks, Historia Ecclesiastica.

11 Cf. Chabot, Chronicon, pp. 16-2o (the pagination of the Syriac text is given in the margins of the translation).

12 For a critical analysis of the chronicles of Michael the Syrian, the anonymous Chronicle of 1234, and Bar 'Ebroyo see Weltecke, "A Renaissance in Historiography". For Dionysius' history and reconstitution see Palmer, Seventh Century, pp. 85-221. Abramowski, Dionysius von Tellmahre, pp. 130-144 has edited and translated these fragments. See also Witakowski, Chronicle of Pseudo-Dionysius, passim.

13 This is discussed at length in Wissa, "Yusab of Alexandria". See also Debié, L'écriture de l'histoire, 2015, pp. 148-149. About the story of the uprising see Debié, L'écriture de l'histoire, 
As has been previously mentioned, a growing body of literature offers accounts of events from non-Arab Islamic perspective. Of particular interest are the social revolts that spread in the early caliphate, namely the Kharijite ("extremist") rebellions, the Abbasid revolution, and Alid uprisings. These revolts were prompted by religious and military-political motivations. Under the Umayyads, several rebellions were triggered by heavy taxation incumbent upon dhimmis.

During the first decades of their rule (i.e. the second half of the 8th century A.D.), the Abbasids, who had periodically supported revolts against the government of Umayyad Cordoba, faced serious problems in Baghdad later in the gth century A.D. Indeed, they could no longer indulge in operations to destabilise the Umayyads. This internal tension raised doubts about the survival of a centralized Abbasid government. The turning point came under the reign of the Abbasid caliph al-Ma'mūn (ruled 813-833). Well prior to his arrival in Baghdad, al-Ma'mūn's main concerns had been the suppression of internal rebellion and the reassertion of control over provinces such as Qom, Yemen, Syria and Egypt which continued to rebel. ${ }^{14}$ This process turned out to be less than successful.

Ethnic Arab governors ruled Egypt as a province until the middle of the 9 th century. These governors were appointed by firstly the Umayyad and later by the Abbasid caliphs. ${ }^{15}$ During more than two hundred years of Arab-Islamic rule there was a high turnover of governors whose involvement in Egypt was mostly exploitative by nature. Income was generated from both. ${ }^{16}$ Over years, the fiscal burden increased incrementally to reach a breaking point and by the mid-8th century wholesale dissatisfaction with Muslim tax officers increased as evidenced by papyri. ${ }^{17}$ The Coptic patriarchs steadily lost authority to administer the affairs of the Church and people. Some accounts clearly depict

p. 148. The Syriac narrative of the Bashmūric revolt in gth century Egypt is to be found in the Chronicle of 1234, pp. 266-267; Michael the Syrian XII, 16, pp. 522-524; Michael the Syrian XII, 17, p. 527 .

14 Rebellions in the early Abbasid period are discussed in Abou El Fadl, Rebellion and Violence, $p p$. 76; 85-87. See also Kennedy, "Egypt as a Province", pp. 79-83.

15 For the beginnings of Umayyad rule, see Foss, "Egypt under Mu'āwiya".

16 Frantz-Murphy, Arabic Agricultural Leases; idem, "Economics of State Formation"; Sijpesteijn, "The Arab Conquest"; idem, "Profit Following Responsibility"; idem, "Landholding Patterns", especially p. 130 n. 49 for the Muslim tax officers.

17 For a discussion of the value of the Arabic documentary material for research on Coptic and Arab Egypt, see among other authors Reinfandt, "Arabic Papyrology". See also Reinfandt, "Administrative Papyri". 
plunder by tax officers and local governors alike. ${ }^{18}$ Such grievance was motivated by the desire for self-enrichment but also the need to finance the ArabByzantine wars at the northern borders of the caliphate. Inevitably between 725 and 832 both Copts and Muslims revolted repeatedly and on a number of occasions, but all revolts were speedily suppressed.

The History of the Patriarchs describes Bashmūr as swampy marshes of narrow sandy banks with thickets and reeds. In pharaonic times, the country of the $H_{3} w$ Nbwt extended eastward to Lake Burullus across the Northern Delta. The land was a wet jungle of trees, reeds and papyrus where fishermen, hunters, shepherds and cattle pastoralists lived..$^{19}$ Wild boar, antelopes, gazelles, varieties of deer, ibex, countless numbers of birds, fish, crocodiles and hippopotami thrived in this wild environment. Evidence from the Ancient Egyptian Old, Middle and New Kingdom tomb paintings suggest that hunting in the marshes included fowling, fishing and possibly the killing of hippopotami. ${ }^{20}$ Textual evidence from the early pharaonic times until the Pharaoh Apries (589-570 в.C.E.) refers to the $H_{3} w N b w t$ as a ruthless population arriving by sea and settling in the coastal banks of the Delta. ${ }^{21}$ During the Greco-Roman period, the $H_{3} w$ Nbwt came to be known as Bukoloi, an aggressive population of herdsmen of cows, and their lands being given the Greek name of Elearchia. To Elearchia corresponds the Coptic Picharôt and the Arabic al-Bashrūd, both denoting a large area of wetland and marshes extending to the east of Rosetta where the Bashmūrites were living in their boats or among the reeds which

18 For a Coptic account of this see Evetts, History of the Patriarchs, p. 486. Documentary sources for the practice of collecting taxes under Muslim rule are discussed in Trombley, "Documentary Background". An example for Abbasid taxation practice is recorded in the seven Arabic tax receipts of a Christian tax payer from Madīnat al-Fayyūm in the late 9 th century A.D.; see Reinfandt/Vanthieghem, "Archives fiscales".

19 Butzer, "Delta".

20 For the Old Kingdom, see Montet, Scènes de la vie privée. As for the Middle and New Kingdoms, depictions of hunting and fishing in the marshes of the Delta are recurrent themes in the Middle and Upper Egypt's necropoleis. For the New Kingdom Theban tombs of Menna, Nakht and Rekhmira see Davies, Tomb of Rekh-mi-r', pl. lxxxii.

21 For a more detailed insight into the $H_{3} w$ Nbwt see Wissa, "Yusab of Alexandria". An example in Coptic for the ancient Egyptian word $H_{3} w$ in the term $H_{3} w N b w t$, meaning "near by", comes from the Coptic manuscripts in the John Rylands collection, which Crum also translated in his Coptic Dictionary as "beyond"; see Crum, Coptic Dictionary, p. 735 and, for the Coptic manuscripts, Crum/Crawford, Catalogue of the Coptic Manuscripts, p. 48. On the term Nbwt, which was non-ethnic, cf. Dussaud, “Les Haou-Nebout”, 175-177; Vercoutter, "Les Haou-Nebout". 
covered the marshy banks, selling papyrus or fishing. ${ }^{22}$ This wilderness provided natural protection from invasions for several centuries. ${ }^{23}$

\section{$3 \quad$ The Uprising}

By 831 A.D., the Copts in the marshlands of Bashmūr were the only insurgents. ${ }^{24}$ Whilst uprisings spread in Bashmūr, the Abbasid caliph al-Ma'mūn had dispatched an army led by the Persian-Muslim leader al-Afshin to quash the revolts. ${ }^{25}$ Later on, he sought the mediation of the Coptic patriarch Yūsāb I and his Syrian counterpart Dionysius of Tell Mahre. ${ }^{26}$ In the end, the social revolt had achieved little, and the Bashmūrites were heavily defeated. ${ }^{27}$ Their villages and churches were burnt and their people crushed. ${ }^{28}$

An aftermath of this violent event was the first wave of mass conversions to Islam. ${ }^{29}$ In Egypt, conversion to Islam had been a long and complex process,

22 Hogarth, "Three Delta Nomes", p. 13, s.v. Picharôt = Elearchia; Carrez-Maratray, Paralia with a detailed study of the toponym of Elearchia; Maspero/Wiet, Matériaux, s.v. al-Bachrud and its Coptic equivalent Picharôt. On the Arabic toponym of al-Bashrūd cf. Cooper, Medieval Nile; Timm, Das christlich-koptische Ägypten, s.v. Bashrud. For the marshy nature of the terrain and the bellicose nature of its herdsmen-inhabitants, see Tagher, Christians in Muslim Egypt, p. 81; Gabra, "Revolts of the Bashmuric Copts", p. 114. In view of the alphabetic nature of Dialect $G$, "Bashmūric" or "Manșūric", which reflects a reduced version of the Coptic alphabet with remarkable absence of the majority of the Coptic uncials, it is highly likely that these Bashmūrites were exposed to both Coptic and Greek cultural and linguistic influences. See Kasser, "Lidiome de Bashmour"; idem, "Prolégomènes", pp. 102-103; Kasser/Shisha-Halevy, "Dialect G”. See also Kasser, "KAT’ASPE ASPE", p. 41.

23 "Bashmuric Revolts", p. 350: "The Bashmuric region was the only part of Egypt where the Arabic authorities could not apply their policy of settling Arabic tribes among the native population to prevent revolts".

24 The 9th century Egyptian Muslim historian al-Kindī in his Kitāb al-Wulāt wa-kitāb alquḍàt mentions the Arab and Coptic rebellion of Jumādā I 216/June-July 831; see Guest, Governors and Judges of Egypt, pp. 189-192. On this rebellion see also Mikhail, From Byzantine to Islamic Egypt, pp. 75-76; Gabra, "Revolts of the Bashmuric Copts"; Megally, "Bashmuric Revolts"; Quatremère, Recherches critiques.

25 Evetts, History of the Patriarchs, pp. 487-488.

26 Chabot, Chronique de Michel le Syrien, pp. 76-77.

27 Al-Kindī in his gth century Kitāb al-Wulāt wa-kitāa al-quḍāt claims that "al-Ma'mūn went to Bashrūd and ordered Afshīn to execute captured Copts and to sell children and women into slavery. He left a long trail of blood behind him, leaving the country after 49 days"; cf. Guest, Governors and Judges of Egypt, pp. 189-192.

28 Evetts, History of the Patriarchs, p. 494.

29 On the Islamisation of Egypt see Lapidus, "Conversion of Egypt", pp. 257 and 26o; Mikhail, From Byzantine to Islamic Egypt, pp. 68-70; Décobert, "Sur l'arabisation”; Bulliet, Conversion; Becker, Beiträge zur Geschichte Ägyptens, pp. 81-148; Dennet, Conversion, 
but the 9th century events and the last Bashmūric revolt turned things upside down. Often enough the jizya is considered to have been the main factor for conversion to Islam by many Copts. There were more reasons, however, one being a general ostracization of the Coptic Church in that era. ${ }^{30}$ Another one was a spread of Mu'tazili teaching (the official caliphal Muslim dogma) in Egypt that had a strong push back effect on local Christian teaching. ${ }^{31}$ Last Bashmūric Rebellion

In their stories, literary choices of both their Coptic and Syriac authors can be spotted. Narrative mediation in the Coptic and Syriac historiographical traditions is introduced as a supplemental approach to more conventional efforts at transforming the conflict: it carries with it a certain perspective and methodology. The first tripartite negotiations are well documented as showing words of peace and destruction. Here, from historiography, it is possible to evaluate the lexicon in which politics and religion have a common history. By considering some of the similarities between the two patriarchs, who emerged as promoters of conciliation we shall see the deployment of this idea as best understood by a conservative response to Muslim intimidation of the Bashmūrites in the Syriac account. The language usage and other elements of the Coptic narrative in the History of the Patriarchs show dialectical variants and a different strategy from the Syriac chronicle.

There is a tendency in the History of the Patriarchs to underline the obedience of the Coptic Church's hierarchy to its Muslim rulers. ${ }^{32}$ Thus the description of the caliph al-Ma'mūn, the image of a caliphal authority in John's text, serves religious and political purposes. ${ }^{33}$ Equally, the rhetoric of al-Ma'mūn

pp. 85-88 and 115; Frantz-Murphy, "Conversion". On conversion specifically during the Abbasid period see Brett, "Population and Conversion"; Lev, "Coptic Rebellions".

30 Together with the Syriac and Armenian churches, the Coptic Church was viewed as a non-Chalcedonian Miaphysite (sometimes wrongly mistakenly referred to as Monophysite) church.

31 Swanson, Coptic Papacy, p. 38.

32 Evetts, History of the Patriarchs, pp. 487-506.

33 Evetts, History of the Patriarchs, p. 488: "When the father patriarch, Abba Joseph, learnt that al-Ma'mūn had arrived, and in his company the patriarch of Antioch, he gathered the bishops together and journeyed to Fusțâț-Mișr, to salute the caliph according to the respect which is due to princes". Swanson, Coptic Papacy, p. 10 explains that the encounter and verbal exchanges between the Coptic Patriarch (as the church authority) and the caliph (here as the supreme civil authority) later became part of the story of the Egyptian church. 
functions as a means to indicate the patriarchal legitimate authority. In subsequent excerpts, John issued an illustration of the Bashmūrites that reveals empirical evidence. He considers the causes and offers his own opinion on a number of matters with an axe to grind and a message to send, and he provides an extended description of how the Bashmūrites break from both the church and Abbasid administration. The contested patriarchal authority alienated the Bashmūrites from both their civil and religious leaders. John shows how patriarch Yūsāb I interacted with his community as a medium of religious ideology and power and how his call to the insurgents remained unanswered. Yūsāb emphasised his various forms of rhetoric, using his spiritual leadership as a tool to achieve conciliation. Through his correspondences Yūsāb even quoted passages of the Holy Scriptures with allusions to St Paul. Whilst Yūsāb's terminology in relation to the vocabulary for "peace" is not explicit, his reasoning is evident in his view, destruction is the antithesis to pacification. There can be nothing in-between. Thus, the author of the History of the Patriarchs presents the violent consequences, such as death, deportation, and enslavement, of the Bashmūrites' disobedience. ${ }^{34}$

\section{Consequences: Forced Migration, Deportation, and Enslavement}

The Syriac chronicle History of Dionysius of Tell Mahre has some similarities with its Coptic counterpart in depicting the Syriac patriarch's good relations with the Abbasid caliph al-Ma'mūn. The Syriac author Dionysius' style and narrative are authoritative. This can be explained by the fact that the Syriac writer had not been captivated by the rebellion, providing him with the freedom to develop an assertive discourse. Information about events, the psychology and conditions of the Bashmūrite community is encoded in Dionysius' diction and is enriched by its associations with a form of verbalisation and a mode of expression.

No doubt, Dionysius did strive for vividness in his narrative. He initiates the reader into a dynamic story by using the first-person plural "We", because he was a member of a group himself and thus a direct witness and participant. This is in contrast to John II, the Coptic author who tells the story of the patriarch Yūsāb I and the Bashmūrites. Meanwhile the Bashmūric episode in Dionysius account is slightly different. ${ }^{35}$ The story contains additional information, for example, how the Abbasid army seized a Coptic woman and tried to

34 Evetts, History of the Patriarchs, pp. 488-489; 494.

35 In Dionysius' account Faḍl ordered Dionysius to go with Yūsāb to the Bashmürites. 
ravage her. ${ }^{36}$ Dionysius' phraseology and rhetoric in respect of conciliation are explicit: he uses the word "peace" in opposition to "war". He also gives an account of a violent aftermath of the events. In contrast to the Coptic account, the Syriac narrative provides additional information on the fate of surviving Bashmūrites, describing how prisoners among the Bashmūrites were subsequently deported to Iraq and thereat enslaved as a consequence of their rebellion. ${ }^{37}$

\section{6}

\section{Conclusion}

In 1940, Rudolf Abramowski provided a first analysis of the Syriac chronicle History of Dionysius of Tell Mahre. Half a century later, in 1987, Witold Witakowski presented another historiographical study of Dionysius' history by sketching the origins of the genre he pursued. He analysed the author's historiographical organisation: short chronicle scheme, chronologically arranged date lemmata, with material from sources of non-chronicle character. In 1993, eventually, Andrew Palmer advanced a new interpretation of Syriac historiography and contributed to a rehabilitation of Dionysius as a trustworthy historical source. ${ }^{38}$ The episode of Bashmūr, however, goes unmentioned in any of these three studies. The historiographical tradition of the last revolt of Bashmūr, as reflected in the accounts of John II and Dionysius respectively, is meant to emphasize the strategic role that the church had in the early Islamic state. Christian leaders appealed historiography as a means for hewing out their own destiny.

The rebellion of Bashmūr represents a singular and tragic moment in the memory of Egypt. The Bashmūrite natural propensity for rebellion against any ruling elite, as is highlighted earlier in this chapter, is a prominent theme. Their implication as inveterate troublemakers is acknowledged in the Coptic narrative. The Syriac source, in contrast, highlights that the Bashmūrites dared to stir, and not to fight against the rulers; only as a supplicant for the fiscal burden, they approached the Muslim administrators begging for conciliation. The Abbasids for their mass deportation took drastic measures. Viewing in its entirety the tale of the Bashmūric woe in the Coptic and in the Syriac narratives becomes an interesting case study, irrespectively of the incomplete account of

$36 \quad$ Chabot, Chronique de Michel le Syrien, pp. $76-78$.

37 Chabot, Chronique de Michel le Syrien, pp. 82-84.

38 Abramowski, Dionysius von Tellmahre; Witakowski, Chronicle of Pseudo-Dionysius; Palmer, Seventh Century. The question of intertextuality, the reliability of the information, and the problems of copying are thoroughly discussed in Weltecke, Beschreibung der Zeiten; Debié, L'écriture de l'histoire. 
deportation. The literary challenge was to create a monolithic "Bashmūr" from two source materials where raw brutality, pillage, forced migration, enslavement, and more significantly, death were common practice.

An intertwining sequence of events in the last Bashmūric rebellion provides us with a view of Coptic-Muslim relations in early Islamic Egypt, which prominently features society with sectarian fiscal politics. This steered Egypt to social fragmentation, financial ruin and revolts which may have prompted the displacement and enslavement of the population of Bashmür. Because of this particular pressure, the response of Yūsāb I, the Coptic patriarch, contrasted sharply with the efforts of Dionysius to mediate the escalation of the situation. The Bashmūrites cast their actions as a defence of Coptic Christians from the vehicle of Arabisation and Islamisation. The discourse around "peace", which is not directly explicit in Yūsāb's vocabulary, shaped the development of a chronic resistance whereas the Syriac patriarch Dionysius had made claim to this language. Yūsāb exhorts from destruction while Dionysius, as one of the three actors, is at the heart of the story of peace and war.

Recent developments in the Middle East have generated a renewed concern for conciliation and stability. The last rebellion of Bashmūr, its possible solutions of peace and reconciliation, and ultimately its consequences associated with displacements in gth century Egypt may serve a standard of comparison. Indeed, current uprisings in the Middle East are echoed in Medieval Islam. The 9th century A.D. marks a turning point in the history of revolts with more resonance today.

\section{Bibliography}

\section{Primary Sources}

Brooks, E.W. (ed. and transl.), Historia Ecclesiastica Zachariae Rhetori Vulgo Adscripta, Part II (Corpus Scriptorum Christianorum Orientalium, 84/Syr 39 T; 88/Syr 42 V), Paris 1921-24.

Chabot, J.-B., Chronicon ad annum Christi 1234 pertinens. Vol. 2, Paris 1917.

Chabot, J.-B., Chronique de Michel le Syrien, Patriarche Jacobite d'Antioche (1166-1199). Éditée pour la première fois et traduite en français, tome III, Paris 1905 (repr. Bruxelles 1963).

Evetts, B.T.A. (ed. and transl.), History of the Patriarchs of the Coptic Church of Alexandria. Part IV: Mennas I to Joseph (849) (Patrologia Orientalis, X, fasc. 5), Paris, 1910, pp. $473^{-665}$.

Guest, R. (ed.), The Governors and Judges of Egypt (E.J.W. Gibb Memorial Series, 19), Leiden 1912. 
Maqrīzī, Taqī al-dīn Abū al-'Abbās al-, Kitāb al-Mawā'iz wa-li- 'tibārfí dhikr al-khițațwal-äthār, ed. A.F. Sayyid, 5 vols., London 2002-2005.

Moosa, M., The Syriac Chronicle of Michael Rabo (the Great). A Universal History from the Creation, Teaneck NJ 2014.

Palmer, A., The Seventh Century in the West-Syrian Chronicles (Translated Texts for Historians, 15), Liverpool 1993.

\section{Secondary Literature}

Abou El Fadl, K., Rebellion and Violence in Islamic Law, Cambridge 2001.

Abramowski, R., Dionysius von Tellmahre, jakobitischer Patriarch von 818-845. Zur Geschichte der Kirche unter dem Islam (Abhandlungen für die Kunde des Morgenlandes, 25.2), Leipzig 1940.

Becker, C.H., Beiträge zur Geschichte Ägyptens unter dem Islam. Zweites Heft, Strasbourg 1903.

Brett, M., "Population and Conversion to Islam in Egypt in the Medieval Period", in U. Vermeulen/J. van Steenbergen (eds.), Egypt and Syria in the Fatimid, Ayyubid and Mamluk Eras. IV: Proceedings of the gth and roth International Colloquium organized at the Katholieke Universiteit Leuven in May 2000 and May 2001, Leuven 2005, pp. $1-32$.

Bulliet, R.W., Conversion to Islam in the Medieval Period. An Essay in Quantitative History, Cambridge MA 1979.

Butzer, K.W., Art. “Delta”, in: W. Helck/E. Otto (eds.), Lexikon der Ägyptologie, vol. 1, Wiesbaden 1975, pp. 1043-1052.

Carrez-Maratray, J.Y., Paralia. Recherches sur la côte du Delta égyptien d'après la documentation grecque et latine (virème s. av. / viIème s. apr. J.C.). Étymologie et Toponymie liées au littoral, unpubl. Ph.D. diss., François Rabelais University Tours 2005.

Cooper, J.P., The Medieval Nile. Route, Navigation, and Landscape in Islamic Egypt, Cairo 2014.

Crum, W.E.A., Coptic Dictionary, Oxford 1939.

Crum, W.E.A./Crawford, J.L.L., Catalogue of the Coptic Manuscripts in the Collection of the John Rylands Library, Manchester 1909.

Davies, N. de G., The Tomb of Rekh-mi-r'at Thebes, New York 1943, pl. LXXXII.

Debié, M., L'écriture de l'histoire en syriaque: transmissions interculturelles et constructions identitaires entre hellénisme et Islam (Late Antique History and Religion, 12), Leuven 2015.

Décobert, C., "Sur l'arabisation et l'islamisation de l'Égypte médiévale”, in: idem (ed.), Itinéraires d'Égypte: Mélanges offerts au père Maurice Martin, S.J., Cairo 1992, pp. 273-300.

Dennet, D., Conversion and the Poll-Tax in Early Islam, Cambridge MA 1950. 
Den Heijer, J., Art. "History of the Patriarchs of Alexandria", in: A.S. Atiya (ed.), The Coptic Encyclopedia, vol. 4, New York 1991, pp. 1238-1242.

Den Heijer, J., Mawhub ibn Manșur ibn Mufarriğ et l'historiographie copto-arabe: étude sur la composition de l'Histoire des Patriarches d'Alexandrie (Corpus Scriptorum Christianorum Orientalium, Subsidia, 83), Leuven 1989.

Den Heijer, J., "L'Histoire des Patriarches d'Alexandrie, recension primitive et Vulgate", Bulletin de la Société d'Archéologie Copte 2 (1985), pp. 1-29.

Dussaud, R., Review of J. Vercoutter, "Les Haou-Nebout", Syria 27 (1950), pp. 175177.

Foss, C., "Egypt under Mu'āwiya", Bulletin of the School of Oriental and African Studies 72 (2009), pp. 1-23; 259-278.

Frantz-Murphy, G., "The Economics of State Formation in Early Islamic Egypt", in: P.M. Sijpesteijn/L. Sundelin/S. Torallas Tovar/A. Zomeño (eds.), From al-Andalus to Khurasan. Documents from the Medieval Muslim World, Leiden/Boston 2007, pp. 101-114.

Frantz-Murphy, G., Arabic Agricultural Leases and Tax Receipts from Egypt, 148-427 AH/765-1035 AD: Arabic Texts, Vienna 2001.

Frantz-Murphy, G., "Conversion in Early Islamic Egypt: The Economic Factor", in: Y. Ragib (ed.), Documents de l'Islam médiéval, Cairo 1991, pp. 11-17.

Gabra, G., "The Revolts of the Bashmuric Copts in the Eighth and Ninth Centuries", Hallesche Beiträge zur Orientwissenschaft 36 (2003), pp. 111-119.

Hogarth, D.G., "Three Delta Nomes", Journal of Hellenistic Studies 24 (1904), pp. 1-19.

Kasser, R., “KAT’ASPE ASPE. Constellations d'idiomes coptes plus ou moins bien connus et scientifiquement reçus, aperçus, pressentis, enregistrés en une terminologie jugée utile, scintillant dans le firmament égyptien à l'aube de notre troisième millénaire", in: L. Painchaud/P.-H. Poirier (eds.), Coptica, Gnostica, Manichaica: Mélanges offerts à Wolf-Peter Funk, Québec 2006.

Kasser, R., "Prolégomènes à un essai de classification systématique des dialectes et subdialectes coptes selon les critères de la phonétique, III, Systèmes orthographiques et catégories dialectales", Le Muséon 94 (1981), pp. 91-152.

Kasser, R., "Lidiome de Bashmour”, Bulletin de l'Institut Français d'Archéologie Orientale 75 (1975), pp. 401-427.

Kasser, R./Shisha-Halevy, A., Art. "Dialect G (or Bashmuric or Mansuric)”, in The Coptic Encyclopedia, vol. 8, pp. 74-75.

Kennedy, H., "Egypt as a Province in the Islamic Caliphate, 641-868", in: C. Petry (ed.), The Cambridge History of Egypt. Vol. 2: Islamic Egypt, 640-1517, Cambridge 1998, pp. $62-85$.

Lapidus, I., “The Conversion of Egypt”, Israel Oriental Studies 2 (1972), pp. 248-262.

Lev, Y., "Coptic Rebellions and the Islamization of Medieval Egypt (8th-1oth century): Medieval and Modern Perceptions", Jerusalem Studies of Arabic and Islam 39 (2002), pp. 303-344. 
Maspero, J./Wiet, G., Matériaux pour servir à la géographie de l'Égypte (Mémoires publiés par les membres de l'Institut français d'archéologie Orientale du Caire, 36), Cairo 1919 .

Megally, M., Art. "Bashmuric Revolts”, in A. Suryal Atiya (ed.), The Coptic Encyclopedia, vol. 2, New York 1991, pp. 349-351.

Mikhail, M.S.A., From Byzantine to Islamic Egypt. Religion, Identity and Politics after the Arab Conquest, London 2014.

Montet, P., Les scènes de la vie privée dans les tombeaux égyptiens de l'Ancien Empire, Paris 1924.

Pillette, P., "L'Histoire des Patriarches d'Alexandrie: Une nouvelle évaluation de la configuration du texte en recensions", Le Muséon 126/3-4 (2013), pp. 419-450.

Quatremère, É., Recherches critiques et historiques sur la langue et la littérature de l'Egypte, Paris 1808.

Reinfandt, L., "Arabic Papyrology and Early Islamic Egypt", Journal of Juristic Papyrology 43 (2014), pp. 209-239.

Reinfandt, L., "Administrative Papyri from the Abbasid Court in Samarra (AD 836-892): A First Report", in P. Schubert (ed.), Actes du 26e Congrès international de papyrologie. Genève, 16-21 août 2010, (Recherches et Rencontres 30). Genève: Librairie Droz S.A., 2012, pp. 639-645.

Reinfandt, L./Vanthieghem, N., "Les archives fiscales de Mīnā, fils de Damarqūra, un contribuable copte du IXe siècle", in J.L. Fournet/A. Papaconstantinou (eds.), Mélanges Jean Gascou. Textes et études papyrologiques (P.Gascou) (Travaux et mémoires, 20/1), Paris 2016, pp. 52-58.

Sijpesteijn, P.M., "The Arab Conquest of Egypt and the Beginning of Muslim Rule", in R.S. Bagnall (ed.), Egypt in the Byzantine world, 300-70o, Cambridge 2009, pp. 437-459.

Sijpesteijn, P.M., "Landholding patterns in early Islamic Egypt", Journal of Agrarian Change 9 (2009), pp. 120-133.

Sijpesteijn, P.M., "Profit Following Responsibility. A Leaf from the Records of a Third/ Ninth Century Tax-Collecting Agent", The Journal of Juristic Papyrology 31 (2001), pp. 91-132.

Swanson, M.N., The Coptic Papacy in Islamic Egypt, 641-1517, Cairo/New York 2010.

Tagher, J., Christians in Muslim Egypt. An Historical Study of the Relations between Copts and Muslims from 640 to 1922 (Arbeiten zum spätantiken und koptischen Ägypten, 10), Altenberg 1998.

Timm, S., Das christlich-koptische Ägypten in arabischer Zeit. Vol. 1: A-C (Tübinger Atlas des Vorderen Orients. Reihe B, 41/1), Wiesbaden 1984.

Trombley, F.R., "The Documentary Background to the History of the Patriarchs of ps.Sawīrus ibn al -Muqaffa' ca. 750-969 C.E”., in: P.M. Sijpesteijn/L. Sundelin/S. Torallas Tovar/A. Zomeño (eds.), From al-Andalus to Khurasan. Documents from the Medieval Muslim World, Leiden/Boston 2007, pp. 131-152. 
Vercoutter, J., “Les Haou-Nebout”, Bulletin de l'Institut Français d'Arcéologie Orientale 46 (1947); 48 (1948).

Weltecke, D., "A Renaissance in Historiography? Patriarch Michael, The Anonymous Chronicle AD 1234 and Bar 'Ebroyo", in H. Teule (ed.), The Syriac Renaissance, Leuven 2010, pp. 95-111.

Weltecke, D., Die "Beschreibung der Zeiten" von Mor Michael dem Großen (1126-1199). Eine Studie zu ihrem historischen und historiographiegeschichtlichen Kontext (Corpus Scriptorum Christianorum Orientalium, 594, Subs. 110), Leuven 2003.

Wissa, M., "Yusab of Alexandria, Dionysius of Tel-Mahre, Al-Ma'mun of Baghdad, the Bashmurites and the Narrative of the Last Rebellion in 'Abbasid Egypt. Re-considering Coptic and Syriac Historiography". in P. Buzi/A. Camplani/F. Contardi (eds.), Coptic Society, Literature and Religion from Late Antiquity to Modern Times. Proceedings of the Tenth International Congress of Coptic Studies, Rome, September 17th-22th, 2012 (Orientalia Lovaniensia Analecta, 247), Leuven 2016, pp. 1045-1062.

Witakowski, W., The Syriac Chronicle of Pseudo-Dionysius of Tel-Mahrē. A Study in the History of Historiography (Acta Universitatis Upsaliensis, Studia Semitica Upsaliensia, 9), Uppsala 1987. 